\title{
CLIMATE CHANGE HAZARDS MITIGATION POLICIES IN THE FRAME OF THE ADMINISTRATION LEVELS IN EGYPT
}

\author{
Somaya ABOELNAGAª, Tamás TÓTH ${ }^{b}$, György Iván NESZMÉLYIc \\ a Ph.D. student Szent István University, Hungary; Lecturer Assistant, Urban Regional Development Dep., \\ Faculty of Urban and Regional Planning, Cairo University, Egypt, e-mail: somayanaga@cu.edu.eg \\ ${ }^{\mathrm{b}}$ Prof. Dr. habil. Tamás Tóth PhD, Vice Rector, Professor of the Institute of Regional Economics and Rural \\ Development, Szent István University, 2100 Gödöllö, Páter Károly str. 1. Hungary; e-mail. \\ Toth.Tamas.Argi@gtk.szie.hu \\ ${ }^{c}$ Dr. habil. György Iván Neszmélyi PhD, Professor of the Institute of Commerce, Budapest Business School - \\ University of Applied Sciences, 1155 Budapest, Markó str. 29-31, Hungary; e-mail: Neszmelyi.Gyorgy@uni- \\ bge.hu
}

Cite this article: Aboelnaga, S., Tóth, T., Neszmélyi, Gy. (2019). Climate change hazards mitigation policies in the frame of the administration levels in Egypt. Deturope. 11(2), 185-201.

\begin{abstract}
Much more evidence has accumulated over the past ten years to indicate that changes in many physical and biological systems are linked to global warming. Then, needing an action for mitigating the climate change impacts through regional development policies target all regions (urban, rural and undeveloped areas) and cities in order to support job creation, business competitiveness, economic growth, sustainable development, and improve citizens' quality of life. And to make it easy to be implemented, so it has to be integrated with the administration levels to achieve the final aim for those objectives. Awareness of the need for a new approach is driven by the observation, in the frame of administration levels on all levels national, regional and local levels. Defining the legal policies and rules to mitigate climate change on regional level by supporting the environment and achieve development on local and regional levels parallelly. Therefore, the research seeks to offer some proactive applicable policies that can dispense with one of the challenging problems. The problem deals with the threats that climate change could have on the development potentialities and natural resources of developing states in the skeleton of the administrative layers. The research aims to utilize the development policies and projects for mitigating the risk level for climate change hazards in the frame of administration levels in Egypt.
\end{abstract}

Keywords: Climate Change, adaptation, mitigation, administration, Egypt

\section{INTRODUCTION}

Lots more evidence has piled up over the past ten years to show that changes in many physical and biological systems relate to global warming. Then, needing an action for mitigating the climate change impacts through regional development policies target all regions (urban, rural and undeveloped areas) and cities in order to support job creation, business competitiveness, economic growth, sustainable development, and improve citizens' quality of life. The final aim to achieve those objectives that has to integrate the administration levels (Adger, el al., 2005). 
Understanding of the demand for a raw approach is pushed by the observation that past policies have broken to reduce regional disparities significantly and have not been able to help individual lagging regions to capture up, despite the allocation of significant public financing. The result is under-used economic potential and weakened social cohesion. It is reflected in the country competitive dynamic regions aiming to achieve their economic, social and environmental objectives (Stern, 2007). Regional development policies complement national macroeconomic and structural policies. In this context, the regional outputs aim at helping countries get regions and cities "right" through the adaptation of policies to the specificities of where people live and work and so improve citizens' well-being. (Eversole and Martin, 2005)

Egypt's administration system is composed of two levels, the central and local levels. The central level consists of ministries, central agencies, and public enterprises. The local level consists of governors, which in turn are classified into two types of hierarchies, those with a complex structure and those with a simple structure. The simple structure governors are composed of three levels: governors, city and district levels. The structure governors consist of four levels: governorate, Markaz, city/village and district levels. The local administration system is currently governed and ruled by law 43 issued in 1979, which was based on the previous 1971 constitution (Ahmed, 2016)

The Main Components of the Local Administration System in Egypt; According to act 43/1979 and its amendments, Egypt is divided into (27) major units called governors. These governors are classified into either fully urban governors of simple structure, or mixed urban and rural governors of complex structure, consist of three levels: governorate, city, and district.

\section{THEORETICAL BACKGROUND}

Confronting the impact of climate change requires local, regional and international cooperation. This is a tremendous and sophisticated challenge which humanity is faced with, for the current and future generations. The government of Egypt undertakes its activities based upon the principle of common responsibilities at the domestic level. In collaboration with the international community, the government implements the key objectives, while considering the social and economic indicators, as well as the social dimension. The government adopts its national policies and measures, based on the fact that these are vital for the protection of existing investments, and simultaneously secures growth and sustainable development (Aaref, 2015)

The National Strategy aims at achieving the following goals 1 . Increasing the flexibility of the Egyptian community in dealing with the risks and disasters caused by climate change and 
its impact on different sectors. These sectors include the coastal zones, water resources and irrigation, agriculture, health; urban areas, housing \& roads and tourism. This goal can be achieved by carrying out an in-depth analysis of the current situation in different sectors of the community (Bulkeley, 2006). These are the facilities that are available and required to raise the degree of preparedness of confrontation and flexible interaction with developments (Friesecke, et al, 2012).

2. Enhancing the capacity to absorb and contain climate-related risks and disasters. This is attained through the development of specialized sectorial programs and action plans to meet the needs of the community at large, and to adapt to the new conditions through various means, ranging from basic fundamentals to the use of state-of-the-art technologies (Bulkeley,2006). In this manner, systems are set up for adaptation to potential climate changes, namely temperature increase and water scarcity, and the adverse expectations on the increase and decrease of precipitation and sea level rise (ESPACE, 2008).

3. Reduction of climate change- related disasters. This is feasible through accurate scientific calculations; field and theoretical observation of the different sectors of the community; appropriate support of the existing projects; selection of the most convenient and appropriate locations and designs for new projects; and strengthening the infrastructure in a manner that would help reduce the disasters related to climate change. (Azab, 2009)

The population distribution is $94 \%$ of the population along $7 \%$ out of all areas, and the area of Egypt is around 1 million $\mathrm{m}^{2}$. Egypt's population in 2017 was approximately 100 million and had increased by $2.3 \%$ per year over the last 10 years (EEAA, 2010). Egypt is a developing country with a growing population and a growing economy. Egypt's population would reach 119 million by 2030 .

\section{DATA AND METHODS}

In the course of elaboration of the present study the research methodology we applied was the interpretation and understanding in a comprehensive way for what are the mitigation policies for climate change hazards in Egyptian regions according to the administrative laws. The novelty of our examinations also derives from the fact that as far as we know it, there has not been any research on this issue to determine the mitigation policies on the Egyptian regions from the legality perspective. The main method was qualitative research study through documents and reports reviews such as the administration laws and environmental reports of Egypt. The aim of developing and acceptance of adapting inquiry as understanding deepens and the situations change; analysing existing data - on inductive way - involve in detail to discover 
important patterns, themes, and interrelationships to investigate the effective policies through theoretical perspective. At first we had an overview on the climate change hazards in Egypt. Next, we determined the major environmental issues in Egyptian administration levels. Finally, we discussed certain policies which aim to adapt and mitigate climate change within Egyptian regions.

\section{RESULTS AND DISCUSSION}

\section{Governmental actors involved in administration levels in Egypt}

The key administrator and legislative entities involved in territorial governance at the different levels according to the 1971 constitution and the different objects of legislation is the most prominently planning law no. 70/1973, Local administration law no. 43/1979 and the Building Law no 119/2008, (Fig. 1).

Figure 1 Key governmental entities involved in planning at the different levels

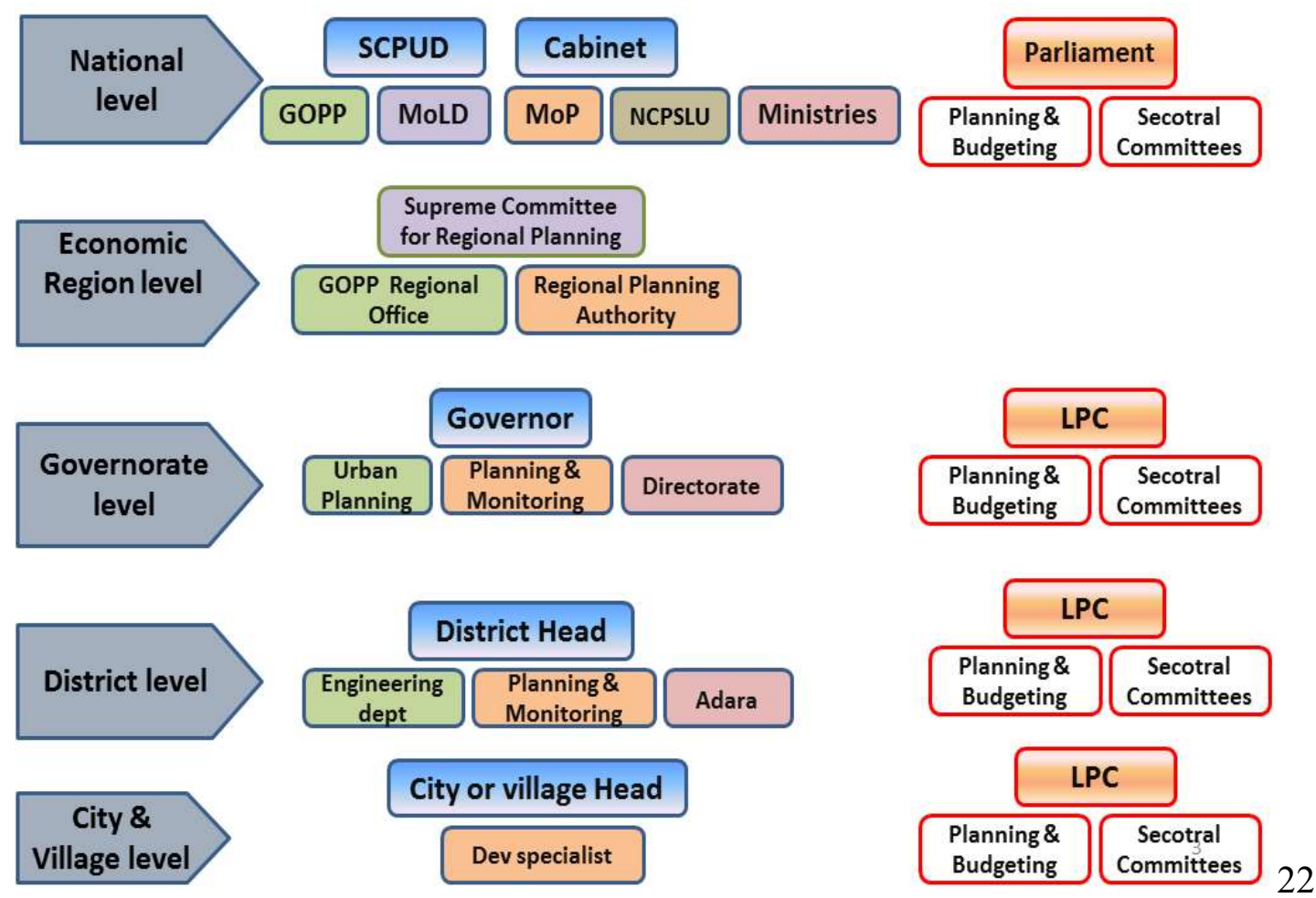

Source: (Ahmed, 2016)

\footnotetext{
22 * SCPUD Supreme Council for Planning and Urban Development, * GOPP General Organization of Physical Planning, * MoLD Ministry of Local Development, * MoPIC Ministry of Planning and International Cooperation, * NCPSLU National Centre for Planning State Lands Usage, * LPC Local Popular Council
} 
a) National level:

Key National-level institutions in Egypt are involved in territorial governance and planning for regional economic development. There are four main entities within the central government that are directly involved in territorial governance at the national level, these entities are: The Ministry of Planning and International Co-operation (MoPIC); the General Organization of Physical Planning (GOPP); the National Centre for Planning State Lands Usage (NCPSLU); and the Supreme Council for Planning and Urban Development (SCPUD), headed by the Prime Minister. (Ahmed, 2016)

b) Economic regions and regional institutions:

Economic regions were not mentioned in the Egyptian constitution, however, according to the article no. 161 of the constitution, administrative units could be created if there is a need. Economic regions were created by presidential decree in 1977. In 1979, the local administrative law was issued with a chapter dedicated to the economic regions and the regional planning authorities. All the same, these changes did not provide economic regions with any actual power as they are without real planning powers and budgetary authority and do not bear the strong executive machinery that connects to the deconcentrated offices of central ministries. (Ahmed, 2016)

There are currently seven economic regions each with a capital: 1) Cairo Region: Cairo is the capital; 2) Alexandria Region: Alexandria is the capital; 3) Delta Region: Tanta is the capital; 4) Suez Canal Region: Ismailia is the capital; 5) Northern Upper Egypt Region: Menia is the capital; 6) Asyout Region: Asyout is the capital; 7) Southern Upper Egypt Region: Aswan is the capital.

c) Local administrative units:

The Local Popular Council (LPC), according to the constitution, is part of the executive authority and is formed for each administrative unit (Governorate, Markaz, city, District, and village local administration), by direct election. The constitutional amendments of 2008 explicitly mentioned decentralization and empowerment of administrative units and stipulated that a gradual transfer of competences from the central level to the local popular council should be granted. The local administration law stipulates in article 27 that the governor is the "representative of the President in the governorate, and shall take charge of supervising the execution of the State General Policy, and s/he has a complete authority over all services utilities and production within the scope of the governorate." (Ahmed, 2016)

\section{The administrative challenges for the environmental issues in Egypt}

Since the mid-1980s, Egypt has introduced different components and measures in its economic reform and structural adjustment programmes to reduce the budget deficit, sustain economic 
growth and improve the standard of living. From the beginning of the $21^{\text {st }}$ century until the 25 January revolution, a rapid acceleration in growth took place, making Egypt one of the Middle East's fastest-growing economies and resulting in the creation of record numbers of jobs. Also, investor confidence remained relatively high. (Azab, 2009)

The expansion in economic activities was mainly in the fields of energy, construction, and telecommunications as well as labour-intensive sectors such as agriculture and manufacturing. In 2005, the Egyptian Competitiveness Report (ECR) records notable improvements in Egypt's competitiveness rankings, reflecting the impact of these significant economic reforms (Condon, et al, 2009). This was reflected in an impressive leap of Egypt's ranking in the third pillar of the Global Competitiveness Index, "macro-economy index", from $81^{\text {st }}$ to $50^{\text {th }}$ place. Having said that, Egypt did not perform as well on Michael Porter's Business Competitiveness Indicator (BCI), which focuses on the "micro foundations of competitiveness" which include the quality of the business environment operations and the sophistication of company strategy. The results indicate that major work must be done at the macroeconomic level to improve the business environment if growth is to be sustainable. (Mahmoud, 2012)

The main challenges facing environmental issues in Egypt are:

\section{(a) Confusion in the Legal Framework Governing Planning for Regional Economic}

Development. The legal basis for planning in Egypt stems from two key laws: the planning law no. 70/1973 which regulates the process of developing the national socioeconomic plan; and the Building Law no. 119/2008 which regulates the process of undertaking the strategic planning process at different levels (national, regional, governorate, cities and village levels) (Betsill,2005).

Both laws offer two parallel, conflicting and contradicting approaches to planning. While the methodology adopted in the Building law is more in line with decentralization, both plans are managed centrally (ESPACE, 2008).

This has led to confusion about: who is leading the planning process (MoPIC ${ }^{23}, \mathrm{GOPP}^{24}$, or line ministries-but it is clear it not local government); who is responsible for integrating between different sectors (MoPIC or GOPP -Not local government); at which level this integration should occur (at the national level as in the Planning Law or at each and every level as in Building Law). (Ahmed, 2016)

\footnotetext{
${ }^{23}$ MoPIC Ministry of Planning and International Co-operation

${ }^{24}$ GOPP General Organization of Physical Planning
} 
The presidential decree contradicts with the roles given to the GOPP in the building law with respect to planning outside the settlements' Zamam.

Planning Law No 70 for the year 1973: The national socioeconomic plan:

- Aims at raising the standard of living, melting differences between classes through the increase of the national income, expansion of the services scope till reaching a sufficient and just community.

- Should ensure the comprehension and integrity of the plan which guarantees for it the use of all national physical, natural and human resources.

- Should ensure the economic, administrative and geographical distribution of projects in a way that guarantees the establishment of economic regions beside the local administrative units.

- Done centrally with safeguarding the widest participation by the local ruling units, the economic units and the public in the preparation of the plan and its execution.

- Is a long-term general national plan which gets divided into time phases of medium terms, and these, in turn, are divided into annual detailed plans. (Mahmoud, 2012)

Strategic Planning According to the building Law No 119 for the Year 2008: The Strategic Plan (Ahmed, 2016):

- It is the plan which defines the future vision for urban development.

- It could be on the national, regional, governorate, city, or village's level.

- It exhibits the objective, policies, economic and social development plans, and the urban environment necessary for sustainable development.

- It defines future requirements for urban expansion, use of diverse lands, programs, priorities, execution mechanisms, and financial resources for each planning level.

The National Centre for Planning State Land Uses (Presidential decree number 153 for the year 2001) (Aaref, 2015)

- Counting and the reformation of the state lands outside the reins and the preparation of the general planning for their development within the framework of the general policy of the country.

- The preparation of the maps of the uses of the state lands outside the reins in all the purposes in coordination with the Ministry of Defence.

- Giving each ministry the maps of the lands specified for the uses of its activities, known that it will have complete and free authority in the specialization and the supervision of the uses of these lands and how to develop them. 
- The restriction and handling of the annual programs of the development and the uses of the lands of each ministry and budgeting the revenues and expenditures of these developments.

- The coordination between the ministries concerning the land pricing rules and the system of their sale and the collection of their value and organizing their protection.

- Assuring that the Treasury of the state gets the net income from the land development that was allocated to each ministry.

- Preparing special studies for the state lands outside the reins that have not been previously allocated, and coordinating with the different state authorities to plan the ideal use of these lands.

- The coordination with the Ministry of Defence regarding the different uses of the lands outside the ruins of what does not contradict the affairs of defending the country.

- Keeping all of the data related to the state lands outside the reins and what has been allocated for them to each ministry and the annual uses of these lands and what remains of them without being used.

- Preparing detailed maps for planning the state lands that are outside the reins, according to the general map of planning.

- Expressing the opinion in the ministries' and the different state authorities' requests for the modification of the lands that have been previously allocated or the lands that have been added to them.

- Expressing the opinion in the disagreements that arise between the ministries and the public authorities and the local administration units or between these authorities and the individuals about specifying the authority responsible for managing and using the disputed lands outside the reins.

- Preparing the studies and the technical and environmental researches necessary for the state land uses outside the reins in coordination with the ministries and the concerned authorities in the country. (Wiesel and Modell, 2014)

(b) Weak Institutional Relationship Between Public Research Institutions and Universities and Regional and Local Actors Engaged in Economic Development; According to the Local Administration Law, the governor shall act to support cooperation between the governorate institutions, universities and research institutes which are located within the governorate area, to serve the environment and promote the local society. However, the governor role in practice is very limited in the coordination of research endeavours and 
economic development at the local level since such research efforts are predominately either executed at or planned by the central level. (Ahmed, 2016)

\section{The main environmental challenges in the administration levels}

As highlighted in the challenges above, Egypt, predominantly follows the hierarchical and topdown approach to territorial governance. The lead organization for managing territories is the central government (in planning for regional development, regional policy setting, land administration, implementation of development projects, and financing) (Betsill, 2005). In this situation, ministries and central agencies mandated with economic development follow an administrative decentralization model whereby they create deconcentrated offices at the regional level, which do not coordinate with each other and are not accountable to the regional institutions or local administrative units. (Ahmed, 2016)

\section{Clarify the planning approach that will be adopted at the regional level.}

The different institutional actors, including the RDAs25, will have different roles in the planning process. The reforms' ultimate goal is to enable the RDA to lead the planning for economic and urban development, in accordance with the state general policies and a framework for regional planning drafted by the central government highlighting key regional polices and guidelines. This envisioned reform will not be achieved instantly, but will require a gradual shift of planning competences from national level institutions to the RDAs. (Eversole and Martin, 2005)

\section{The staged approach towards reforming territorial governance}

Lessons learned from international experience suggest that the best way to approach territorial governance is to introduce the reform based on a long-term vision combined with gradual and incremental actions. Enabling the RDA is not an easy fix and would require continuous efforts on the ground to enhance the organizational capacity at the regional level. Likewise, in this new setting, new roles will be assigned to the government at the central level, which will require time and tailor-made capacity building interventions. (Denhardt and Denhardt, 2009)

\footnotetext{
${ }^{25}$ The RDA model means that there is a specific set of regional institutions established that are still under the oversight of the central government, but which possesses a set of competences and resources that allow it to develop policies appropriate to its territory.
} 
A national policy framework for regional development by the MoPIC, GOPP, and NCPSLU to specify the Egyptian government's vision for sustainable development and how this would impact on economic, environmental, and social planning policies. The framework will provide parameters within which regions can produce their own Regional Strategic Spatial Plan for Economic Development. These strategic plans specify the vision for the economic development of each region (Greiving \& Fleischhauer, 2012). They spell out the major economic development interventions that will be carried out at the regional level. The plans will cover a long-term period (20-30 years) but with a detailed 5 year plan which is linked to the budget. During the first phase, the planning process will be facilitated by the central level, however, with strong engagement of the RDA and regional partners. (Wiesel and Modell, 2014)

The strategic planning department at the RDA will work closely with MoPIC, GOPP, NCPSLU, and the National Planning Institute to draft the strategic plans. In addition, the department will be drafting a midterm and annual investment plans based on the regional strategic plans as well as the state general policies and the policy framework for regional development prepared by the central government.

Ensure Stakeholder engagement with the RDA through different mechanisms: The regional law should highlight different mechanisms that enable the engagement of the different stakeholders within the region with the RDA and its board. Among these mechanisms could be a regular stakeholder consultation process; reinforcing the engagement of different actors during the environmental and social impact assessment; engagement during the planning process; consultation process on the progress of key performance indicators; among others. For the stakeholders' engagement to be meaningful, access to information should be granted, including information about proposed regional plans and strategies, regional competitiveness reports, regional budget and the report of the Central Agency for Accounting. (Eversole and Martin, 2005)

\section{Sectoral impacts of climate change}

Climate change - with its many dimensions (social, environmental, economic and political) - is expected to lead to multiple impacts at various scales and levels. The impacts on natural ecosystems will be reflected on all socioeconomic levels, affecting livelihoods and human wellbeing. The prevailing climatic conditions in the Arab region have highly significant impacts on the different components of the ecosystems. Major impacts could be attributed to the inherent 
fragility of the dominating arid ecosystems of the region. These arid ecosystems are generally characterized by inferior physiochemical properties, the weak resilience of soil resources and relatively-limited availability of surface/ground-water resources. (Burton et al, 2002)

1. Water resources: Nine out of fourteen countries in the Middle East and Nord African (MENA) region already have an average per capita water availability below the water scarcity threshold. A warming climate is expected to place additional stresses on water resources in the MENA countries, whether or not future rainfall is significantly altered (Hume et al., 2015). Per capita renewable water resources in the region, which in 1950 were $4,000 \mathrm{~m}^{3}$ per year, are currently $1,100 \mathrm{~m}^{3}$ per year. Trends of reduced surface water availability, reduced groundwater reserves, and increased occurrence of drought and flood events have been observed in several countries (e.g. in Morocco over the last 30 years). Projections indicate that per capita renewable water resources will drop by half, reaching $550 \mathrm{~m}^{3}$ per person per year in 2050 (World Bank, 2006). Countries expected to experience decreased precipitation include: Egypt, Jordan, Lebanon and the Occupied Palestinian Territory (IPCC, 2007).

Rising temperatures and changes in runoff patterns will influence the flow of rivers upon which countries in the region depend.

2. Agriculture and food security: Agricultural production and food security are closely linked to the availability of water. Climate change is expected to affect food security through its impact on agriculture and food production systems. At the global level, aggregate agricultural output potential will be less affected by climate change, with significant variations between regions. According to the (IPCC, 2007), by the 2080s, agricultural potential could increase by $8 \%$ in developed countries, primarily as a result of longer growing seasons, while in the developing world, it could fall by $9 \%$, with sub-Saharan Africa and Latin America projected to experience the greatest losses. (Mueller and Rynne, 2009)

The majority of Arab countries are considered among the world's most water scarce, and in many places demands for water have already exceeded supply. Higher temperatures and less rainfall will reduce the flow of rivers and streams, slow the rate at which aquifers recharge, and make the entire region more arid (Greiving \& Fleischhauer, 2012). These changes will have a series of effects, particularly on agriculture, energy and food security.

The main climate change risks in the North African and Middle East region will largely be linked to long-term desiccation and drought associated with climatic variability. Water stress is of huge importance and decreases in water availability may have severe impacts on food security (Sanchez -Rodriguez, 2009). Some projections indicate that under moderate increases 
in temperature, water flow will be largely impacted. This is true for the Euphrates and Jordan Rivers, which could shrink by $30 \%$ and $80 \%$, respectively, by the end of the century. (Adger et al, 2005)

3. Sea level rise, coastal inundation and erosion: The extremely low elevation of arable cropland in the Nile Delta in Egypt makes sea level rise a clear threat for the country, as most of the $50 \mathrm{~km}$ wide land strip along the river is less than $2 \mathrm{~m}$ above sea-level and is protected from flooding by only a 1 to $10 \mathrm{~km}$ wide coastal sand belt. Erosion of this protective sand belt, which is essential for the protection of the lagoons and the low-lying reclaimed lands, could be a serious problem (Watts, el al., 2015). The impacts would be very serious, as one-third of Egypt's fish catch is made in lagoons. Erosion could also affect the water quality and productivity of agricultural lands.

Infrastructure, roads, and recreational tourism, beach facilities would be endangered, and essential groundwater would be contaminated with salt. Based on the UN-Habitat's State of the World's Cities 2008/09, by 2070 coastal cities that could be severely affected by rising sea levels include Alexandria (Egypt). (IPCC, 2007)

\section{Climate Change hazards mitigation policies of the administration levels in Egypt:}

According to administration levels and their relation to mitigating the climate change hazards, the following Tab. 1 illustrate how could mitigation policies work on the regional level. And Tab. 2 shows how this mitigation policies work for the different regions in Egypt according to their hazards.

Table 1 mitigation policies for climate change hazards along Economic regions and regional institutions in Egypt

\begin{tabular}{|l|l|l|l|}
\hline \multirow{2}{*}{ Level } & \multicolumn{3}{|c|}{ Climate Change Mitigation Policies } \\
\cline { 2 - 4 } & Water resources & \multicolumn{1}{|l|}{$\begin{array}{l}\text { Agriculture and food } \\
\text { security }\end{array}$} & $\begin{array}{l}\text { Sea level rise, coastal } \\
\text { inundation and erosion }\end{array}$ \\
\hline $\begin{array}{l}\text { Regional } \\
\text { (Economic } \\
\text { regions) }\end{array}$ & $\begin{array}{l}\text { - organization for managing territories (in planning for regional development, } \\
\text { regional policy setting, land administration, implementation of development } \\
\text { projects, and financing) }\end{array}$ \\
\cline { 2 - 4 } & $\begin{array}{l}\text { - New irrigation } \\
\text { techniques } \\
\text { - Water recycle usage }\end{array}$ & $\begin{array}{l}\text { - Use different water } \\
\text { resources }\end{array}$ & $\begin{array}{l}\text { - Create bumpers in the } \\
\text { highlands }\end{array}$ \\
\hline $\begin{array}{l}\text { Sub-regional } \\
\text { (Regional } \\
\text { institutions- } \\
\text { Governmental) }\end{array}$ & $\begin{array}{l}\text { - highlighting key regional polices and guidelines } \\
\text { for garden irrigations }\end{array}$ & $\begin{array}{l}\text { - Use the new agriculture } \\
\text { techniques } \\
- \text { Develop the crop cycles }\end{array}$ & $\begin{array}{l}\text { - Rocky barriers, sea } \\
\text { walls, wave barriers } \\
- \text { Beach maintenance }\end{array}$ \\
\hline
\end{tabular}

Source (Authors) 
Table 2 mitigation policies for climate change hazards along economic regions in Egypt

\begin{tabular}{|c|c|c|c|}
\hline \multirow[t]{2}{*}{ Region } & \multicolumn{3}{|c|}{ Climate Change Mitigation Policies } \\
\hline & Water resources & $\begin{array}{l}\text { Agriculture and food } \\
\text { security }\end{array}$ & $\begin{array}{l}\text { Sea level rise, coastal } \\
\text { inundation and erosion }\end{array}$ \\
\hline 1) Cairo & $\begin{array}{l}\text { - Water recycle usage } \\
\text { for garden irrigations }\end{array}$ & - & - \\
\hline $\begin{array}{l}\text { 2) } \\
\text { Alexandria }\end{array}$ & $\begin{array}{l}\text { - Water recycle usage } \\
\text { for garden irrigations }\end{array}$ & - & $\begin{array}{l}\text { - Rocky barriers, sea } \\
\text { walls, wave barriers } \\
\text { - Beach maintenance }\end{array}$ \\
\hline 3) Delta & $\begin{array}{l}\text { - New irrigation } \\
\text { techniques } \\
\text { - Water recycle usage }\end{array}$ & $\begin{array}{l}\text { - Use different water } \\
\text { resources } \\
\text { - Develop the crop cycles } \\
\text { - Use the new agriculture } \\
\text { techniques }\end{array}$ & $\begin{array}{l}\text { - Rocky barriers, sea } \\
\text { walls, wave barriers }\end{array}$ \\
\hline $\begin{array}{ll}\text { 4) Suez } \\
\text { Canal }\end{array}$ & $\begin{array}{l}\text { - Water recycle usage } \\
\text { for garden irrigations }\end{array}$ & - & $\begin{array}{l}\text { - Rocky barriers, sea } \\
\text { walls, wave barriers }\end{array}$ \\
\hline $\begin{array}{l}\text { 5) Northern } \\
\text { Upper Egypt }\end{array}$ & $\begin{array}{l}\text { - New irrigation } \\
\text { techniques } \\
\text { - Water recycle usage }\end{array}$ & $\begin{array}{l}\text { - Use different water } \\
\text { resources } \\
\text { - Develop the crop cycles } \\
\text { - Use the new agriculture } \\
\text { techniques }\end{array}$ & $\begin{array}{l}\text { - Create bumpers in the } \\
\text { highlands }\end{array}$ \\
\hline 6) Asyout & $\begin{array}{l}\text { - New irrigation } \\
\text { techniques } \\
\text { - Water recycle usage }\end{array}$ & $\begin{array}{l}\text { - Use different water } \\
\text { resources } \\
\text { - Develop the crop cycles } \\
\text { - Use the new agriculture } \\
\text { techniques }\end{array}$ & - \\
\hline $\begin{array}{l}\text { 7) } \text { Southern } \\
\text { Upper Egypt }\end{array}$ & $\begin{array}{l}\text { - New irrigation } \\
\text { techniques } \\
\text { - Water recycle usage }\end{array}$ & $\begin{array}{l}\text { - Use different water } \\
\text { resources } \\
\text { - Develop the crop cycles } \\
\text { - Use the new agriculture } \\
\text { techniques }\end{array}$ & $\begin{array}{l}\text { - Create bumpers in the } \\
\text { highlands }\end{array}$ \\
\hline
\end{tabular}

Source (Authors)

\section{CONCLUSION}

Climate change impacts through regional development policies target all regions and cities in order to support job creation, business competitiveness, economic growth, sustainable development, and improve citizens' quality of life. The government adopts its national policies and measures, based on the fact that these are vital for the protection of existing investments, and simultaneously secures growth and sustainable development.

The National Strategy aims at achieving the following goals: 1. Increasing the flexibility of the Egyptian community in dealing with the risks and disasters. 2. Enhancing the capacity to engage and contain climate-related risks and disasters for adapting temperature increase and water scarcity, and the precipitation and sea level rise. 3. Reduction of climate change- related 
disasters; field and theoretical observing the different sectors of the community; appropriate support of the existing projects; locations and designs for new projects.

The main challenges facing environmental issues in Egypt are:

(a) Confusion in the Legal Framework Governing Planning for Regional Economic Development; The legal basis for planning in Egypt stems from two key laws: 1. Planning Law No 70 for the year 1973: The national socioeconomic plan; 2. Strategic Planning According to the building Law No 119 for the Year 2008: The Strategic Plan; 3. The National Centre for Planning State Land Uses (Presidential decree number 153 for the year 2001): Counting and reforming the state lands and preparing the general planning.

(b) Weak Institutional Relationship Between Public Research Institutions and Universities and Regional and Local Actors Engaged in Economic Development; According to the Local Administration Law, the governor shall act to support cooperation between the governorate institutions and universities and research institutes which are located within the governorate area, to serve the environment and promote the local society. However, the governor role in practice is very limited in the economic development at the local level that efforts are predominately either executed at or planned by, the central level.

For the environmental issues; Clarify the planning approach that will be adopted at the regional level: The different institutional actors, will have different roles in the planning process. The reforms' goal to lead the planning for economic and urban development, in accordance with the state general policies and a framework for regional planning drafted by the central government.

Sectoral impacts of climate change: Climate change - with its many dimensions (social, environmental, economic and political) - is expected to lead to multiple impacts at various scales and levels. The impacts on natural ecosystems will be reflected on all socioeconomic levels, affecting livelihoods and human well-being. The prevailing climatic conditions in the Arab region have highly significant impacts on the different components of the ecosystems. Major impacts could be attributed to the inherent fragility of the dominating arid ecosystems of the region. These arid ecosystems are generally characterized by inferior physiochemical properties, the weak resilience of soil resources and relatively-limited availability of surface/ground-water resources.

\section{SUMMARY}

Climate change impacts through regional development policies target all regions and cities in order to support business competitiveness, economic growth, sustainable development, and improve citizens' quality of life. Understanding of the demand for a raw approach is pushed by the observation that past policies have broken to reduce regional disparities significantly and have not been able to help individual 
lagging regions to capture up, despite the allocation of significant public financing. It is reflected in the country competitive dynamic regions aiming to achieve their economic, social and environmental objectives. Egypt's administration system is composed of two levels, the central and local levels. The central level consists of ministries, central agencies, and public enterprises. The local level consists of governors, which in turn are classified into two types of hierarchies, those with a complex structure and those with a simple structure. The simple structure governors are composed of three levels: governors, city and district levels. The structure governors consist of four levels: governorate, Markaz, and district levels. Confronting the impact of climate change requires local, regional and international cooperation. The government of Egypt undertakes its activities based upon the principle of common responsibilities at the domestic level. In collaboration with the international community, the government implements the key objectives, while considering the social and economic indicators, as well as the social dimension. The government adopts its national policies and measures, based on the fact that these are vital for the protection of existing investments, and simultaneously secures growth and sustainable development.

The National Strategy aims at achieving the following goals: 1. Increasing the flexibility of the Egyptian community in dealing with the risks and disasters. 2 . Enhancing the capacity to engage and contain climaterelated risks and disasters for adapting temperature increase and water scarcity, and the precipitation and sea level rise. 3. Reduction of climate change- related disasters; field and theoretical observing the different sectors of the community; appropriate support of the existing projects; locations and designs for new projects.

Governmental actors involved in administration levels in Egypt according to the 1971 constitution and the different pieces of legislation (most prominently planning law no. 70/1973, Local administration law no. 43/1979 and the Building Law no 119/2008). a) National level: involved in territorial governance and planning for regional economic development. b) Economic regions and regional institutions: the local administration law was issued dedicated to the economic regions and the regional planning authorities. c) Local administrative units: (Governorate, Markaz, city, District, and village local administration).

The administrative challenges for the environmental issues in Egypt: From the beginning of the $21^{\text {st }}$ century until the 25 January revolution, a rapid acceleration in growth took place, making Egypt one of the Middle East's fastest-growing economies and resulting in the creation of record numbers of jobs. Also, investor confidence remained relatively high. The expansion in economic activities was mainly in the fields of energy, construction, and telecommunications as well as labour-intensive sectors such as agriculture and manufacturing. Egypt did not perform as well on Michael Porter's Business Competitiveness Indicator, which focuses on the "micro foundations of competitiveness" which include the quality of the business environment operations and the sophistication of company strategy. The results indicate that major work must be done at the macroeconomic level to improve the business environment if growth is to be sustainable.

The main challenges facing environmental issues in Egypt are:

(a) Confusion in the Legal Framework Governing Planning for Regional Economic Development; The legal basis for planning in Egypt stems from two key laws: 1 Planning Law No 70 for the year 1973: The national socioeconomic plan: Aiming to raise the standard of living, melting differences between classes; ensuring the comprehension plan which guarantees for it the use of all national physical, natural and human resources; ensuring the economic, administrative and geographical distribution of projects in a way that guarantees the establishment of economic regions beside the local administrative units; and, getting divided into time phases of medium terms, and these, in turn, are divided into annual detailed plans; and 2 Strategic Planning According to the building Law No 119 for the Year 2008: The Strategic Plan: defines the future vision for urban development; on different levels national, regional, governorate, city, or village's; exhibits the objective, policies, economic and social development plans, and the urban environment necessary for sustainable development; and, defines future requirements for urban expansion, use of diverse lands, programs, priorities, execution mechanisms, and financial resources for each planning level. Both laws offer two parallel, 3 The National Centre for Planning State Land Uses (Presidential decree number 153 for the year 2001): Counting and reforming the state lands and preparing the general planning for their development within the framework of the general policy of the country; giving each ministry the maps of the lands specified for the uses of its activities; Preparing special studies and detailed maps for planning the state lands that are outside the reins; Expressing the opinion between the ministries and the public and local administration units or between these authorities and the individuals about specifying the authority responsible for managing and using the disputed lands outside the reins; and, Preparing the studies and the technical and environmental researches necessary for the state land uses outside the reins in coordination with the ministries and the concerned authorities in the country.

(b) Weak Institutional Relationship Between Public Research Institutions and Universities and Regional and Local Actors Engaged in Economic Development; According to the Local Administration Law, the governor shall act to support cooperation between the governorate institutions and universities 
and research institutes which are located within the governorate area, to serve the environment and promote the local society. However, the governor role in practice is very limited in the economic development at the local level that efforts are predominately either executed at or planned by, the central level.

The main environmental challenges in the administration levels: predominantly follows the hierarchical and top-down approach to territorial governance. The lead organization for managing territories is the central government. Here, the ministries and central agencies mandated with economic development follow an administrative deconcentration model whereby they create deconcentrated offices at the regional level, which do not coordinate with each other and are not accountable to the regional or local administrative units.

Clarify the planning approach that will be adopted at the regional level: The different institutional actors, including the RDAs, will have different roles in the planning process. The reforms' goal to lead the planning for economic and urban development, within the state general policies and a framework for regional planning by the central government highlighting key regional polices and guidelines, which will not be achieved but will require a gradual shift of planning competences from national level to the RDAs. Sectoral impacts of climate change: Climate change with its many dimensions (social, environmental, economic and political) - is expected to lead to multiple impacts at various scales and levels. On natural ecosystems will be reflected on all socioeconomic levels (livelihoods and human well-being). The prevailing climatic conditions in the MENA region have highly significant impacts on the different components of the ecosystems. Major impacts could be attributed to the inherent fragility of the dominating arid ecosystems. These arid ecosystems are generally characterized by inferior physiochemical properties, the weak resilience of soil resources and relatively-limited availability of surface/ground-water resources. 1 Water resources: Nine out of fourteen countries in the MENA region already below average per capita water availability. A warming climate is expected to place additional stresses on water resources in the MENA countries. 2 Agriculture and food security: closely linked to water availability. Climate change is expected to affect food security through its impact on agriculture and food production systems. At the global level, aggregate agricultural output potential will be less affected by climate change, with significant variations between regions. 3 Sea level rise, coastal inundation and erosion: The extremely low elevation of arable cropland in the Nile Delta in Egypt makes sea level rise a clear threat for the country, as most of the $50 \mathrm{~km}$ wide land strip along the river is less than $2 \mathrm{~m}$ above sea-level and is protected from flooding by only a 1 to $10 \mathrm{~km}$ wide coastal sand belt.

\section{REFERENCES}

Aaref, A. (2015). A Critique of Administrative Reform Programs in Egypt Implications from Riggs' Prismatic Model. Developing Country Studies. ISSN 2225-0565

Adger, W. N., Arnell, N. W., \& Tompkins, E. L. (2005). 'Successful Adaptation to Climate Change Across Scales,' in Global Environmental Change 15, 77-86

Ahmed, S. H. (2016). A Study of The Civil Service Law as Part of Egypt's Administrative Reform. American University in Cairo, Egypt (Doctoral dissertation, AUC).

Azab, N. A. (2009). Assessing electronic government readiness of public organizations: effect of internal factors (case of Egypt) (Doctoral dissertation, Middlesex University).

Betsill, H. B. (2005). Rethinking Sustainable Cities: Multilevel Governance and the 'Urban' Politics of Climate Change. Environmental Politics, Vol?42-63.

Bulkeley, H. (2006). 'A Changing Climate for Spatial Planning' in Planning Theory and Practice, (Vol. 7 (2): 203-214, DOI: 10.1080/14649350600673153).

Burton, I., Huq, S., Lim, B., Piliosova, O., \& Schipper, E. L. (2002). 'From impacts assessment to adaptation priorities: the shaping of adaptation policy,' in Climate Policy, 2, 145-159, DOI: $10.1016 / \mathrm{S} 1469-3062(02) 00038-4$.

Condon, P. M., Cavens, D., \& Miller, N. (2009). Urban Planning Tools for Climate Change. Cambridge: Lincoln Institute of Land Policy.

Denhardt, R., \& Denhardt, J. (2009). Public administration: An action orientation (6th ed.). Belmont, CA: Thomson/Wadsworth.

EEAA. (2010). Egypt state of the Environment report 2009. Egyptian Environmental Affair Agency, Cairo, Egypt 
ESPACE. (2008). Climate Change Impacts and Spatial Planning Decision Support Guidance. Retrieved November 19, 2010, from www.espace-project.org

Eversole, R., \& Martin, J. (2005). Participation and Governance in Regional Development. Ashgate: Aldershot.

Friesecke, F., Schetke, S., \& Kötter, T. (2012). Urban Planning for Climate Change - Position Paper of FIG Working Group 8.1. Planning, Environment and Water Management, 602. Rome, Italy: FIG Working Week.

Greiving, S., \& Fleischhauer, M. (2012). National climate change adaptation strategies of European states from a spatial planning and development perspective. Eur. Plan. Stud. 20, 27-48.

IPCC. (2007). 'Summary for Policymakers' Climate Change 2007: Impacts, Adaptation and Vulnerability - Contribution of Working Group II to the Fourth Assessment Report of the Intergovernmental Panel on Climate Change. Parry: Cambridge University Press.

Mahmoud, N., (2012). The Local Chief Executives: A Comparative Study of International Experiences Focusing on The Role of Governors in Egypt (Master's thesis, American University of Cairo, 2012). Cairo: AUC DAR Repository. [Retrieved: 30 October 2016] from http://dar.aucegypt.edu/handle/10526/3105

Mueller, J., and Rynne, S. (2009). Integrating Energy and Climate into Planning. Chicago: American Planning Association PAS Memo.

Sanchez-Rodriguez, R. (2009). 'Learning to Adapt to Climate Change in Urban Areas. A Review of Recent Contributions,' in Current Opinion in Environmental Sustainability

Stern, N. (2007). The Economics of Climate Change: The Stern Review. Cambridge: Cambridge University Press.

Watts, G., Battarbee, R. W., Bloomfield, J. P., Crossman, J., Daccache, A., Durance, I., ... \& Hess, T. (2015). Climate change and water in the UK-past changes and future prospects. Progress in Physical Geography, 39(1), 6-28. doi:10.1177/03091333145 42957

Wiesel, F., \& Modell, S. (2014). From new public management to new public governance? hybridization and implications for public sector consumerism. Financial Accountability \& Management. 